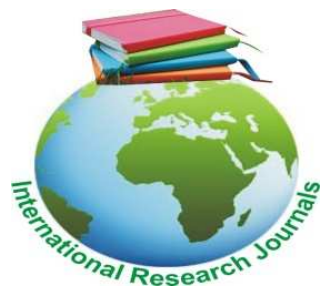

Educational Research (ISSN: 2141-5161) Vol. 8(2) pp. 013-020, April, 2017

Available online@ http://www.interesjournals.org/ER

DOI: http:/dx.doi.org/10.14303/er.2017.022

Copyright (C) 2017 International Research Journals

Full Length Research Paper

\title{
Effect of drama method on students' academic achievement in Christian religious knowledge (CRK) curriculum
}

\author{
*Ugwu C. J., Ogwu E.N. and Igbokwe, U. \\ Department of Arts Education, University of Nigeria, Nsukka \\ *Corresponding Authors' E-mail: ogwue@yahoo.com
}

\begin{abstract}
This study investigated the effect of drama method on students' academic achievement in Christian Religious Knowledge (CRK) in senior secondary schools in Nsukka Local Government Area (NLGA) of Enugu state. Two research questions and two hypotheses guided the study. Quasi-experimental research design was used to collect data from 115 students, randomly selected from1328 senior secondary two (SS11) students offering CRK in public co-educational secondary schools in NLGA. Instrument for data collection was Christian Religious Knowledge Achievement Test (CRKAT) Kuder Richardson Formula $20\left(K_{20}\right.$. Mean analysis was used to answer the research questions while the Analysis of Covariance (ANCOVA) was used to test the hypotheses at 0.05 significant levels. Results revealed that students taught using drama method performed better than those taught with lecture method in CRK; also gender does not matter as far as achievement in CRK is concerned using drama method. Recommendations were made based on findings.
\end{abstract}

Keywords: Achievement, Cristian religious knowledge, Drama method, Students.

\section{INTRODUCTION}

Christian Religious Knowledge (CRK) is one of the subjects approved by the National Policy on Education (2013) to be taught and studied in the secondary schools in Nigeria. The aim is to encourage students to participate in those activities, which foster personal discipline, character training, tolerance, reconciliation and peaceful co-existence. This provides opportunities for Nigerian youths to learn more about God in order to produce well-ordered personalities or citizens of strong characters for the nation (Asogwa and Echemazu, 2011). It produces people that are able to make good and productive life choices to become valuable members of the community (Ede and Odo, 2006); to teach students to respect and tolerate people of other religions, nationalities and ethnic groups (Onah, 2008); to develop an understanding of religious traditions and to appreciate the cultural differences in the world (Deluxe, 2005); to instill discipline and enhance empowerment in Nigerian youths (Nigerian Educational Research and Development Council (NERDC), (2010). In actual sense, CRK forms the moral foundation and teaches ethics of life to the students. Ayogu (2008) noted that without a sound or strong moral foundation, every society and every nation eventually collapses. As stated by NERDC (2010), CRK is an informative and life changing subject which helps the youth to improve their attitude to God and to their fellow men.

In Nigeria today, with the high rate of immorality and indiscipline ranging from cultism, conflicts, killing, kidnapping, stealing, prostitution, exam malpractice, abortion to mention but a few, it becomes vital to reinforce the teaching and learning of CRK. Perhaps, these immoral behaviours could be eradicated if CRK is taught with good teaching methods which will enhance students' achievement in the subject. Method such as direct lecture is believed to increase rote learning, memorization and laziness (Offorma, 2006); yields less deep knowledge (Ajah and Asadu, 2002), which is usually practiced in tertiary institutions like universities (Wagner, 2010). However, Asogwa and Echemazu (2011) observed that CRK is still taught in schools using the traditional method of talk and chalk. This method 
014 Educ. Res.

reduces students' interest and enrolment in CRK thereby make students' achievement very low and poor (Ayogu, 2008). The West African Examination Council (WAEC) chief examiner's reports in 2008, 2009, 2010 and 2011, indicated poor achievement of students in CRK senior school certificate examination (SSCE) and general certificate of education (GCE) respectively. Effective teaching of CRK therefore, will help to eradicate indiscipline among children in Nigerian society. The CRK Secondary School curriculum is therefore designed to teach not only the content of the Holy Bible, but also the moral lessons desirable. These outcries are pointing towards the need for paradigm shift from the conventional method of teaching to an activity based one.

Teaching methods is a means used for instruction in the classroom (Uwameiye and Ojikutu, 2008), which can affect the learners' achievement and interest positively or negatively. The choice of teaching method/s depends on the information or skills that are being taught. Teaching methods may include demonstration, drama, recitation, memorization, lecture method among others. Teaching methods recommended for teaching CRK, include: stories, illustrations, role play, drama, video and audio aids (NERDC, 2010). Among all mentioned, drama is believed to provide active participation and creativity (Ozdemir and Cakmak, 2008) and improves ones skill (Gonen and Dalkilic, 2008); and contributes to human development (Wagner, 2010). In teaching and learning process, drama provides individuals with an opportunity to get encouraged, to have new experiences, to be at peace with oneself and with others, and to be tolerant towards others since every member of the group has the opportunity to participate in the process.

Many researchers believe that achievement is accomplishing whatever goal one have set for oneself, (Tomporowski, Davis, Miller and Naglieri, 2008; Pandey, 2008; Onyilo and Onyilo, 2010). It is seen as the quality and quantity of students' work which is gotten from school, college or university, in a class, in a laboratory, library, or fieldwork (Okeke, 2012) or an outcome of education which varies in individuals (Lansu and Cillessen, 2012).A great deal of research has been on the effect of method on students' achievement level in English teaching at the of drama primary school level in Turkey (Akdag and Tutkun (2010); effects of drama on the performance of at-risk elementary mathematics students in Benue State of Nigeria (Kariuki and Humphrey, 2010);effect of creative drama on students' achievement in the instruction of some development and learning theories among university students (Adiguzel and Timucin, 2010). However, this was based on effect of drama method on achievement of students in CRK in Nsukka local government area of Enugu state Nigeria. Achievement in CRK might not be limited to method but also by gender difference.

Researchers have agreed that gender is socially constructed which is determined by the different roles, rights, and responsibilities individuals take part in (Russell, 2012; Wijk and Francis, 2010). These functions and roles seem to transcend into what learners learn in school which could influence their academic achievement. Researchers like Onyilo and Onyilo (2010) conducted a study on gender and academic achievement using junior secondary school certificate examination (JSSCE) scores in integrated science and social studies. The findings showed that academic achievement was gender sensitive, resulting from the fact that male students scored significantly higher than female students. However, scholars have different views on how gender influences academic achievement. A great number of researchers believe that gender affects students' performance in various subjects such as CRK with females performing better (Asogwa and Echemazu, 2011); in language studies with male excelling more than females (Otagburuagu, Obah, Onuigbo and Okorji, 2007).Egwu (2010), found out that gender has a significant factor in students' achievement in History while Umo (2001), also found out otherwise in Igbo language. However, this study aims at investigating students' academic achievement in CRK using drama method based on their gender.

Research has shown several positive improvement effect of drama on academic achievement of English language students in Turkey (Akdag and Tutkun, 2010), and also in elementary mathematics of pupils in Ghana (Kariuki and Humphrey, 2010). Hence the researcher wants to identify if drama method will have any effect on senior secondary school students' academic achievement in CRK in Nsukka Local Government Area of Enugu State.

\section{Statement of the problem}

The West African Examination Council (WAEC) chief examiner's report from 2008 to 2011 has indicated poor achievement of students in CRK in SSCE and GCE examinations which necessitated this study. The poor performance of Senior Secondary School students in CRK could be traced to the dominant use of lecture method of instruction which appears to activate only one sense organ (Asogwa and Echemazu, 2011). This study therefore is determined to find out the effect of drama method on students' academic achievement in CRK in senior secondary schools in Nsukka Local Government Area.

\section{Theoretical perspective to the study}

Social learning theory is a perspective which states that social behaviour is learned primarily by observing and imitating the action of others. People especially children; learn from the environment by learning through influential 
models (Bandura, 1977). The social learning theory inculcates the spirit of imitation and modeling in the students through the use of drama method. Students while acting drama, participate, interact socially, imitate others behaviours and model by acting various roles. Individuals cannot learn much by observation unless they perceive and attend to the significant features of the modeled behaviour.

In drama method, students are surrounded by many influential models such as characters in drama, friends within their peer group and teachers at school. They pay attention to some of these people (models) and encode their behaviour. At a later time they may imitate the behaviour they have observed. The social learning theory sees man as an active being that can influence his environment and can also be influenced by his environment. Learning takes place through modeling and imitation. The characters in drama are the models while the learners imitate the characters through the process of observation, identification and imitation. Thus, the learner is an active member of the classroom and the society at large.

\section{Significance of the study}

This study has both theoretical and practical significance. Theoretically, this study will add body to already existing knowledge and literature in this field of study which other researchers will refer to while carrying out research. Practically, the study will benefit the teachers, students, curriculum planners, text book writers and the Nigerian society at large.

Findings from this study will be of immense benefit to classroom teachers since it will improve their innovative knowledge on drama method of teaching. Students will equally benefit from this research, because it will make them to be more active and participatory in class, since drama method is active in nature. It will encourage team work thereby increasing friendliness and love for one another which will help in tolerance and character building. It will also help students to achieve more academically, be more informed, and out spoken. As leaders of tomorrow, students are expected to use the knowledge they will gain from this study to solve the leadership problems in Nigeria. It will help the curriculum planners and designers to see the need and importance of drama method and thereby make it a compulsory method of teaching other subjects in secondary schools in Nigeria. Textbook writers will also benefit from this study because it will expose them to produce good and comprehensive textbooks on CRK that will cover drama method of teaching.

The Nigerian society will equally benefit from this study in solving the moral problems that is eating deep into the fabrics of Nigerian society.

\section{Purpose and hypotheses of the study}

The main purpose of this study is to identify the effect of drama method on students' academic achievement in CRK based on their gender in senior secondary schools. Specifically, the study sought to:

1) Identify the effect of drama method on students' achievement in CRK.

2) Determine the effect of drama method on gender and achievement in CRK.

Following from these objectives, the following null hypotheses were posited to be tested at an alpha level of .05 .

$\mathbf{H}_{01:}$ There is no significant difference between the mean achievement scores of students taught CRK using drama method and those taught using conventional method.

$\mathbf{H}_{\text {O2: }}$ There is no significant difference in the mean achievement scores of male and female students taught CRK using drama method and those taught using conventional method.

\section{RESEARCH METHOD}

\section{Design of the study}

This study adopted the quasi-experimental research design using pretest-posttest control group design. Intact classes from two sampled schools were used. As stated by Ali (2006), a quasi-experimental design uses non randomized groups and this option occurs when the researcher cannot randomly sample and assign the subjects to groups. Thus, the researcher used groups already in existence (intact classes). This was to avoid the possible class disruption involved in subject randomization. The design of the study is represented thus: $\mathrm{E}: \mathrm{O}_{1} \mathrm{XD} \mathrm{O}_{2} \mathrm{C}: \mathrm{O}_{1} \mathrm{XL} \mathrm{O_{2 }}$

Where,

$\mathrm{E}=$ Experimental group

$\mathrm{C}=$ Control group

$\mathrm{O}_{1}=$ Pre-test

$X D=$ Drama method

$\mathrm{XL}=$ Lecture method

$\mathrm{O}_{2}=$ Post-test

\section{Area of the study}

This study was carried out in Nsukka Local Government Area of Enugu State. Nsukka Local Government Area has thirty two (32) public secondary schools (Statistics unit PPSMB Nsukka Zone, 2011).This area was chosen for this study because according to the WAEC chief examiner's reports from 2008 to 2011, students in this area have been performing poorly in CRK both in SSCE and GCE examinations respectively. 
016 Educ. Res.

\section{Population of the study}

The population comprised all the senior secondary two (S.S.II) students 1,328 that were offering CRK in public co-educational secondary schools in Nsukka Local Government Area (Statistics Unit PPSMB Nsukka Zone, 2011). This population was chosen to avoid the possible disruption of external examination if the examination class of S.S.S III students were chosen. In addition, the scheme of work, (leadership) is for SS11 students. Coeducational secondary schools were also chosen because gender is an independent variable in this study.

\section{Sample and sampling techniques}

A total number of 115 students constituted the sample of the study. Simple random sampling technique was used to draw two schools that participated in the study. The two schools that participated in the study are Community Secondary School, Alor-Uno and Model Secondary School, Nukka. Both schools are public co-educational Secondary Schools in Nukka Local Government Area. Two intact classes were randomly assigned to treatment and control groups respectively.

\section{Instruments for data collection}

The instruments for data collection for this study are Christian Religious Knowledge Achievement Test (CRKAT) that was adapted from the senior school certificate examination past questions. The CRKAT is made up of 40 items (multiple choice objective questions) with options (A-D). This was designed to measure students' understanding of the content that was taught "leadership". The instrument measured the students' understanding in knowledge, comprehension and application levels of educational objectives. The time that was given for the test was 45 minutes.

The researcher used multiple choice objective questions because it has straight forward questions and answers and was easier to mark to assess the students' level of understanding of the content that was chosen for the study.

Table of specification was formulated by the researcher; it guided the arrangement of CRKAT items under the knowledge, comprehension and application levels of educational objectives. The CRKAT covers four topics that were taught under leadership. They are Joseph as a leader, Moses as a leader, Joshua as a leader and Deborah as a leader. Each topic was given $25 \%$ chance in the CRKAT. Each topic had ten (10) questions, making it forty (40) questions in all. Each question that was answered correctly was awarded $2 \frac{1}{2}$ marks.

\section{Validation of the instruments}

Instrument was content validated by three experts. The three experts from Science Education Department (Measurement and Evaluation) and two experts from Arts Education Department (Education/Religion) respectively were from the University of Nigeria, Nsukka. Experts were requested to assess the instruments with regard to the clarity of items, simplicity of vocabulary, relevance of items to the study, total coverage for use in the collection of data for the study and orderliness of the lesson plan.

\section{Reliability of the instruments}

The reliability of the instruments (CRKAT) was trial tested for internal consistency using 30 students outside the study area. The scores generated were used in calculating the reliability coefficients of the instruments. Trial testing offered the researcher the opportunity to determine whether the CRKAT are useable, valid, reliable and well-spaced in terms of time allotted. Reliability for CRKAT was calculated using Kuder Richardson Formula $20\left(\mathrm{KR}_{20}\right)$. According to Nworgu (2006), $\mathrm{KR}_{20}$ is used to calculate objective questions or dichotomously scored items. The reliability coefficient for Joseph as a leader using 10 (ten) items gave an index of 0.78 ; for Moses as a leader using 10 (ten) items gave an index of 0.73 ; for Joshua as a leader using 10 (ten) items gave an index of 0.64; for Deborah as a leader using 10 (ten) items gave an index of 0.70 . The overall reliability for the four topics (40 items) gave an index of 0.66.

\section{Experimental procedures}

\section{Training of the teachers}

Prior to the actual instruction, training classes were organized for the CRK teachers of the sampled schools that participated in the study. During the training classes, the teachers were instructed on the treatment specifications. The teachers were provided with the validated lesson plans. Each lesson plan contains the instructional objectives, instructional materials, entry behaviour, presentation, evaluation and summary/closure. The teachers for the treatment and control groups were specifically trained. The training sessions were conducted in one of the sampled schools. This training lasted for four days. The sessions were in the evening (4-6 pm) in order not to interfere with the teachers' working hours. On the whole, four CRK teachers from the two sampled schools were involved in the training program. follows: 
DAY 1: The day started with prayers and was followed by the introduction of the participants and the purpose of the training exercise. The teachers were asked to share their experiences with regard to the teaching of CRK - their problems and challenges concerning students' poor achievement in CRK.

DAY 2: Drama and lecture method of teaching of teaching were discussed. The participants were taught what these two methods of teaching are and how to use them. For instance, the participants were taught how the drama skills could be used in teaching and how to use the costumes for drama on different topics and they copied notes.

DAY 3: Presentation and discussion of lesson plans. The two method of teaching (drama and lecture) were further discussed and practiced by the teachers.

DAY 4: Discussion on lesson plans continued with micro teaching to practice among the trainees. All the trainees participated in the micro teaching while the researcher observed, to ensure compliance. When this was done, the researcher recapped the major points and the training session came to an end.

A pretest was administered to the students before the treatment. The experimental and control groups were both pretested before treatment. The content "leadership" was taught to the two groups. This was done under the supervision of the researcher. The control group was taught using the lecture method while the experimental group was taught using drama method. Each lesson lasted for forty five minutes. The experiment lasted for four weeks. The researcher ensured proper classroom control.

At the end of the treatment a common post-test was administered to the two groups. The test items were reshuffled. The scripts were collected and marked and scores were recorded. The data were analyzed based on these scores.

\section{Control of extraneous variables}

The following procedures were adopted by the researcher to ensure that extraneous variables which might influence the findings were controlled.

(a) Pre- test sensitization: Since the same test was used for pretest and post, it was likely that students might become familiar with the test instrument, thereby introducing error into the study. In order to minimize pretest sensitization, the test items were reshuffled before the posttest.

(b) Teacher Variables: This was taken care of by the training organized for the teachers.

(c) Homogeneity of the Instructional Condition: In order to ensure that the instructional conditions were homogenous across the groups, the researcher used the same lesson plans for all the groups taught. (d) Subject Interaction Effect: This was taken care of by selecting experimental and control groups far apart. This was to reduce errors that might arise as a result of interaction and exchange of ideas among the students from the two groups.

(e) Inter Group: In order to eliminate the errors of nonequivalence arising from the non-randomization of the subjects since intact classes were used, the analysis of covariance (ANCOVA) was used to analyze the data, in order to adjust for pre-existing differences in nonequivalent (intact groups).

(f) Maturation: To minimize the effect of maturation and history, the researcher used a short period of four weeks for the research.

\section{Method of data analysis}

Mean scores analyses were used to answer the research questions. The hypotheses were tested using Analysis of Covariance (ANCOVA) at 0.05 level of significance.

\section{RESULTS}

The results are presented in tables according to the research objectives and hypotheses that guided the study. The result in Table 1 shows that the experimental group taught CRK using drama method had a pretest mean of $(M=42.18, S D=10.82)$ and a posttest mean of $(M=54.59, \quad S D=10.81)$. The difference between the pretest and posttest mean for the experimental group was 12.41. The control group taught CRK using lecture method had a pretest mean of $(\mathrm{M}=32.32, \mathrm{SD}=11.21)$ and a posttest mean of $(M=40.66, S D=13.16)$. The difference between the pretest and posttest mean for control group was 8.34.

Results on Table 1 also show that the total pretest mean score for both experimental and control group was $(M=38.32, S D=11.95)$ and a posttest mean of $(M=49.13$, $\mathrm{SD}=13.57)$. The difference between the pretest and posttest mean for the total group was 10.81. However, for each of the groups, the posttest means were greater than the pretest means with the experimental group having the highest mean gain. This is an indication that drama method of teaching has some effects on students' achievement in CRK.

The result in Table 2 shows that the male group had a pretest mean score of $(\mathrm{M}=39.16, \mathrm{SD}=12.09)$ and a posttest $(M=50.72, S D=12.45)$. The difference between the pretest and posttest mean for the male group is 11.56. The female group had a pretest $(M=37.65$, $\mathrm{SD}=11.88)$ and a posttest $(\mathrm{M}=47.87, \mathrm{SD}=14.38)$. The difference between the pretest and posttest mean for female group was 10.22. Results in Table 2 also show that the total pretest mean score for both male and 
018 Educ. Res.

Table 1: Mean Analysis of pretest and posttest achievement scores of students taught CRK using drama method and students taught CRK using lecture method

\begin{tabular}{lcccccc}
\hline Variable & \multicolumn{3}{c}{ Pre test } & \multicolumn{2}{c}{ Posttest } & Mean gain \\
\hline Method of Teaching & $\mathrm{N}$ & $\bar{x}$ & $\mathrm{SD}$ & $\bar{x}$ & $\mathrm{SD}$ & \\
Drama Method & 70 & 42.18 & 10.82 & 54.59 & 10.81 & 12.41 \\
Lecture Method & 45 & 32.32 & 11.21 & 40.66 & 13.16 & 8.34 \\
Total & 115 & 38.32 & 11.95 & 49.13 & 13.57 & 10.81 \\
\hline
\end{tabular}

Table 2: Mean Analysis of pretest and posttest Achievement scores of male and female students taught CRK using drama method and students taught CRK using lecture method.

\begin{tabular}{|c|c|c|c|c|c|c|}
\hline \multirow{2}{*}{$\begin{array}{l}\text { Variable } \\
\text { Gender }\end{array}$} & \multirow[b]{2}{*}{$\mathbf{N}$} & \multicolumn{2}{|c|}{ Pretest } & \multicolumn{2}{|c|}{ Posttest } & \multirow[t]{2}{*}{ Mean gain } \\
\hline & & $\bar{x}$ & SD & $\bar{x}$ & SD & \\
\hline Male & 51 & 39.16 & 12.09 & 50.72 & 12.45 & 11.56 \\
\hline Female & 64 & 37.65 & 11.88 & 47.87 & 14.38 & 10.22 \\
\hline Total & 115 & 38.32 & 11.95 & 49.13 & 13.57 & 10.81 \\
\hline
\end{tabular}

Table 3: Analysis of covariance (ANCOVA) of students' achievement in CRK

\begin{tabular}{lccccc}
\hline Source & $\begin{array}{c}\text { Type III Sum of } \\
\text { Squares }\end{array}$ & df & Mean Square & F & Sig. \\
\hline Corrected Model & $15192.260^{\mathrm{a}}$ & 2 & 7596.130 & 146.321 & .000 \\
Intercept & 2268.965 & 1 & 2268.965 & 43.706 & .000 \\
Pretest & 9876.996 & 1 & 9876.996 & 190.256 & .000 \\
METHODS & 698.589 & 1 & 698.589 & $13.457^{*}$ & .000 \\
Error & 5814.400 & 112 & 51.914 & & \\
Total & 298642.750 & 115 & & & \\
Corrected Total & 21006.661 & 114 & & & \\
\hline
\end{tabular}

a. R Squared $=.723$ (Adjusted R Squared $=.718$ )

female group was $(M=38.32, S D=11.95)$ and a posttest mean of $(M=49.13, S D=13.57)$. The difference between the pretest and posttest mean for the total group was 10.81. However, for each of the groups, the posttest means were greater than the pretest means with the male group having higher mean gain. This is an indication that gender has some influence on the achievement of students taught CRK.

The result in Table 3 shows with respect to the achievement mean scores of students taught CRK using both drama and lecture method resulted in $F(1$, $115)=13.457^{\star}, p<.05$. Hence, the null hypothesis $\left(H_{01}\right)$ was rejected.

Thus, there was a significant difference in the mean achievement scores of students taught CRK using drama method and those taught using lecture method, with the students taught using drama method having a higher mean scoreas indicated in Table 1. This result showed that drama method of teaching resulted in an improvement of students' achievement in CRK.
The result in Table 4 shows that with respect to the achievement mean scores of male and female students taught CRK using drama method and lecture method, gave an $F(1,115)=0.991, p>.05$. Hence, the null hypothesis $\left(\mathrm{H}_{02}\right)$ was not rejected. Thus, there was no significant difference in the mean achievement scores of male and female students taught CRK using drama method and those taught using lecture method. Result indicates that gender does not matter as far as achievement in CRK is concerned using drama method.

\section{DISCUSSION OF FINDINGS}

Findings indicate that students exposed to drama method achieved higher in CRK than those exposed to the conventional (lecture) method of teaching. This result is in line with the findings of Akdag and Tutkun (2010) as well as Kariuki and Humphrey (2010), which indicated that students taught using drama method performed 
Ugwu et al. 019

Table 4: Analysis of covariance (ANCOVA) of male and female students' achievement in CRK

\begin{tabular}{lccccc}
\hline Source & $\begin{array}{c}\text { Type III Sum of } \\
\text { Squares }\end{array}$ & df & Mean Square & F & Sig. \\
\hline Corrected Model & $14550.818^{\text {a }}$ & 2 & 7275.409 & 126.218 & .000 \\
Intercept & 1741.926 & 1 & 1741.926 & 30.220 & .000 \\
Pretest & 14321.785 & 1 & 14321.785 & 248.463 & .000 \\
Gender & 57.147 & 1 & 57.147 & .991 & .322 \\
Error & 6455.843 & 112 & 57.641 & & \\
Total & 298642.750 & 115 & & & \\
Corrected Total & 21006.661 & 114 & & & \\
\hline
\end{tabular}

a. R Squared $=.693$ (Adjusted R Squared $=.687$ )

significantly better in achievement than those taught using conventional method. The significance difference of the drama method over lecture method in CRK could be attributed to the fact that drama method promotes interaction amongst the students and also involves students' active participation in the class.

The Mean analysis on gender revealed that female students achieved higher than the male students in CRK when exposed to drama method of teaching. However, this difference was not significant as shown in the hypothesis. This indicates that gender of students does not matter as far as achievement in CRK is concerned using drama method of teaching and learning. This result is therefore contrary to Egwu's (2010), findings that gender, has a significant factor in students' achievement in History; Asogwa and Echemazu's, (2011) findings that females achieved significantly higher than males in languages; and also to Onyilo and Onyilo's (2010) findings that males achieved significantly higher than females students in science and social studies curriculum. However, there was a convergence in findings with Umo's (2001) that gender difference does not exist as far as achievement in lgbo language was concerned. This result might be as a result of equal attention given to both gender in the class.

\section{CONCLUSION}

Findings indicate that students taught CRK using drama method achieved higher than those taught using lecture method. Gender influences achievement in CRK with males achieving higher than females from their mean difference. Although this difference is not significant enough to conclude that gender influences achievement in CRK when exposed to drama method of teaching. Therefore, gender does not matter as far as using drama method of teaching is concerned in CRK.

\section{RECOMMENDATIONS}

In view of the findings, the following recommendations are made:

- Christian Religious Knowledge teachers should use drama method in teaching senior secondary school students to enhance their performance in CRK.

- The State and Federal Ministries of Education should produce good drama method text books on CRK and distribute them to senior secondary schools. This will go a long way in enhancing students' achievement in CRK.

- The State and Federal Ministries of education should organize conferences and workshops for CRK teachers to expose the teachers on how best to use drama method of teaching.

- School administrators should ensure regular supervision of teachers at regular basis to ensure that drama method of teaching is used in teaching CRK in senior secondary schools.

- Students should engage in this method of learning to ensure peaceful co-existence of individuals through CRK practices.

\section{REFERENCES}

Adiguzel HO, Timucin E (2010). The effect of creative drama on students' achievement in the instrument of some development and learning theories. Procedia-Social and Behavioural Sci., 9(7), 17411746.

Ajah E, Asadu Cl (2002). Effects of role play method of instruction on students' achievement in senior secondary school christian religious knowledge (Unpublished bachelor degreethesis) University of Nigeria, Nsukka.

Akdag N, Tutkun OF (2010). The effect of drama method on achievement level in

English teaching. "knowledge, comprehension and application level. Intel. J. Human Sciences, 7(1), 824-833.

Ali A (2006). Conducting research in education and the social sciences. Enugu: Tashiwa networks Ltd.

Asogwa UD, Echemazu R (2011). Effect of power point presentation on secondary school students' achievement in Christian religious. Intl. J. Educational Res., 11(1), 22-30.

Ayogu Cl (2008). Pedagogical competencies of christian religious knowledge in Obollo education zone (Unpublishedmaster'sthesis) University of Nigeria, Nsukka.

Bandura A (1977). Social learning theory, New York: General Learning Press.

Deluxe E (2005). Changing aims in religioneducation. London: Rowtledge and Regan Paul Publishers. 
020 Educ. Res.

Ede VI, Odo AE (2006). Factors influencing students low interest in the study of CRK in secondary school in isi-Uzo L.G.A (Unpublished bachelor degree thesis)University of Nigeria Nsukka.

Egwu MO (2010). Effects of pictures supported with audio- taped instruction on students' achievement in history (Unpublished master's thesis) University of Nigeria, Nsukka.

Federal Republic of Nigeria (2014). National policy on education ( $6^{\text {th }}$ ed). Lagos: NERDC Press.

Gonen M, Dalkilic N (2008).Cocukegitiminde drama yontemveuyagulamar.Istanbul! Epsilon Yayinciliki.

Kariuki PN, Humphrey SG (2010). The effects of drama on the performance of at-risk elementary math students. Intel. $\mathrm{J}$. Instruction, 1(2), 20-24.

Lansu TM, Cillessen AHN (2012). Peer status in emerging adulthood: Associations of popularity and preference with social roles and behaviour. J. Adolescent Res., 27(1), 132-150.

Nigerian Educational Research and Development Council (NERDC) (2010). Nigerian Senior secondary school curriculum on christian religious studies. Abuja: NERDC Press.

Nworgu BG (2006). Educational Research: Basic Issues and methodology $\left(2^{\text {nd }} E d\right)$.Nsukka: University Trust Publishers.

Offorma GC (ed) (2006).Curriculum implementation and instruction $\left(2^{\text {nd }} e d\right)$. Onitsha: Uni-World Education Publishers (Nig) Itd.

Okeke JO (2012). Educational methods and theories questions. Retrieved (on 8/3/2013) from http://wiki.answer.com.

Onah NG (2008). "Religion and gender problem in Nigeria: The Christian Religious Dimension" inNsukka. Journal of Religious Studies, (2) 1, 31-42.

Onyilo BD, Onyilo OG (2010). Academic achievement and self-concept of secondary school students. J. Res. in National Development, 8(2), 67-88.
Otagburuagu EJ, Obah TY, Onuigbo S, Okorji RI (2007). Teaching English languag skills: A Foundation Course in Educational Linguistics. Nsukka: Anyi-P and Sons Printing Press.

Ozdemir SM, Cakmak A (2008). The effect of drama education on prospective teachers' creativity. Intl. J. Instruction, 1(11), 14-16.

Pandey RG (2008). Academic achievement as related to motivation and parental background. Indian Psychological Revolution, 70(4), 213216.

Russell CD (2012). Gender, Academic and meanings of schooling (Unpublished doctoral dissertations) Columbia University.

Tomporowski P, Davis CI, Miller P, Naglieri J (2008). Exercise and children's intelligence, cognition and academic achievement. Educational Psychology, 20(2), 111-131.

Umo UC (2001). Effect of games on the achievement of junior secondary school students in igbo grammar (Unpublished Doctoral Dissertation) University of Nigeria, Nsukka.

Uwameiye R, Ojikutu RA (2008). Effect of team teaching on the academic achievements of students in introductory technology. Retrieved (on 5/2/2013), from (http://www.itdl.org/journal/oct08/article05.ht/m).

WAEC Chief Examiner's Report 2008-2011.

Wagner BJ (2010). Educational drama and language arts:What research shows. Portsmouth $\mathrm{NH}$ : Heinemann.

Wijk LA. Francis PO (2010).Gender in practice. Swiss agency for development and cooperation. Retrieved (on 8/3/2013) from (http://www.gender.cawater-info.net/what-is/index-e.htm) 